\title{
Pragmatics of English Speech Acts: Compliments Used by Macedonian Learners
}

\author{
Marjana $\operatorname{Vaneva}^{1} \&$ Marija Ivanovska $^{1}$ \\ ${ }^{1}$ School of Foreign Languages, University American College Skopje, Skopje, R. Macedonia \\ Correspondence: Marjana Vaneva, School of Foreign Languages, University American College Skopje, Skopje, R. \\ Macedonia, Treta makedonska brigada 60, 1000 Skopje, R. Macedonia. Tel: +389-2-246-3156. E-mail: \\ vaneva@uacs.edu.mk
}

\author{
Received: May 15, 2018 Accepted: June 12, 2018 Online Published: July 8, 2018 \\ doi:10.5539/ijel.v8n5p272 URL: https://doi.org/10.5539/ijel.v8n5p272
}

\begin{abstract}
This study investigated the pragmatic knowledge and competence of the Macedonian learners of English, i.e. Macedonian high school English students' views on and perceptions of pragmatics, their pragmatic competence in the speech act of complimenting, and the language learning strategies employed in the process of acquiring pragmatic knowledge.

Although "student-oriented" and "evaluation-oriented", the teaching methods currently used do not sufficiently develop students' communicative competence in the process of English teaching and learning. Many students lack pragmatic knowledge of how to use the foreign language in specific settings and how to interpret certain utterances used by native speakers of the other language.

Despite all the efforts made to improve the English language education in Macedonia, yet greater emphasis should be put on students' linguistic and pragmatic competence in the English teaching and learning process. This area is the focus of the current study that analyses the English speech act of complimenting and its use by the Macedonian learners of English.
\end{abstract}

Keywords: complimenting, Macedonian learners, pragmatics, speech acts

\section{Introduction}

\subsection{English Learning and Teaching in the Secondary Education in Macedonia}

Due to the rapid economic development, the role of English, especially the communicative competence in English, which refers to both the knowledge of a language and the ability to use that knowledge in social interactions (Barron, 2003; Hymes, 1972; Widdowson, 1992), has become more and more important in the daily life of the Macedonian population. Hence, it is important to examine how Macedonian learners of English acquire knowledge of the appropriate use of English and how they practice their knowledge in both their learning contexts and daily life in order to help them better develop their language competence. This is done hereby by reconsidering the speech act of complimenting and its use by the Macedonian learners of English.

Since English is the dominant language in the world today, it is universally accepted and used as the official language in the political and academic discourse worldwide (Bamgbose, 2001). English has been the dominant foreign language in the curricula of the educational institutions and the foreign language learning in Macedonia for more than two decades (Ministry of Education and Science, 2015). The process of learning English as a foreign language starts in the $1^{\text {st }}$ grade, i.e. at the age of 6 , when it is introduced as the first foreign language in the Macedonian education system.

In the secondary schools in Macedonia, English is a compulsory course that all students are required to complete during their four years of school and pass all examinations that have been designed to assess their linguistic competence, such as the knowledge of English grammar, syntax and lexis.

The education focuses on the student as a subject in the teaching process, their cognitive and social development, i.e. the development of their independence and self-reliance in the process of learning and acquiring learning strategies as a basis for lifelong learning. The syllabi also focus on the lexicology and grammar of the language, development of communicative skills, cultural aspects of the English-speaking countries, etc. Hence, the focus is 
put on the students, their age, needs and interests as well as on the learning process itself.

Although "student-oriented" and "evaluation-oriented", the teaching methods currently used do not sufficiently develop students' communicative competence in the English teaching and learning process. The syllabi for English as a first foreign language for secondary education, as a compulsory course, are developed based on the Common European Framework of Reference for Languages and students' achievements in the nine-year elementary education. Moreover, they are informed by relevant research, theories and best classroom practices for language teaching and development of students' communicative competence. However, many English students do well in their written tests but fail to communicate effectively with others in spoken English, even in a very simple communication. Although they learn English for several years, starting from elementary education and continuing into secondary education, they still cannot appropriately speak English in situ. These students are called 'mute' and 'deaf' language students (Zhang, 2001) as they have developed a large repertoire of lexical and grammatical knowledge, but they are unable to apply it in real communication because they have limited pragmatic knowledge and competence.

\subsection{Research Questions and Aims of This Empirical Study}

The paper presents a theoretical discussion about explicit pragmatic instructions as a facilitative tool to develop pragmatic competence in a foreign language, which is supported by a study of students' views on and perceptions of pragmatics in high school English learning and teaching, the levels of pragmatic competence in the speech act of complimenting. Hence, there are three research questions covered in this study as follows:

RQ1: What are the Macedonian high school English language students' views on and perceptions of pragmatics in their English learning process?

One objective of this research was to examine Macedonian high school English language students' views on and perceptions of pragmatics. For example, in the questionnaire, students were asked which English: the so-called 'Macedonian' form of English, American English or British English they would like to learn to use. This question was designed to explore students' perceptions of the practical use of English.

RQ2: To what extent do high school English language students in Macedonia focus on their pragmatic knowledge in their English learning? What are their levels of pragmatic competence?

The second objective of the research was to examine the levels of high school English language students' pragmatic competence in three speech act situations that cover the speech act of complimenting. Better learning outcomes would be achieved if students were highly motivated in student-oriented classrooms through effective language learning strategies. Having a clear picture of students' levels of pragmatic knowledge and their language learning strategies could help recognise students' English language in development and provide support for further development in their learning of the target language.

RQ3: How do high school English language students apply their language learning strategies in the pragmatics and English learning process?

The third objective of the research was to understand how high school English language students apply their language learning strategies in the process of learning English and pragmatics. Language learning strategies can help learners learn a language more effectively and become more proficient language practitioners (Kaplan, 2002; Oxford, 1990).

\subsection{Significance of the Study}

Despite all the efforts made to improve English education, yet greater emphasis should be put on students' pragmatic competence in the English teaching and learning process. This area is the focus of the current study that analyses the English speech act of complimenting and its use by the Macedonian learners of English. In addition to pragmatics, this study is also relevant for sociolinguistics, intercultural communication, adoption of language as first or second language, etc.

The study of speech acts is significant for the practice as well. The lack of pragmatic and linguistic competence, i.e. the inadequate application of the forms and functions of speech acts in the interaction of speakers that speak a different mother tongue and who belong to different cultures could cause certain problems in their communication.

Taking into account that pragmatic competence is sometimes neglected in classroom, as well as the evident need of significant pragmatics research and more thorough analysis of the principles that are the basis of communication in society, the arguments presented in this paper may serve as a foundation for foreign language teachers in the process of helping second language learners develop pragmatic skills in the target language. In 
that way, the analysis of speech acts is very significant for the practice as well.

Speech acts are also very significant in the process of foreign language learning as foreign language learners should be able to know what language structures and vocabulary to use in a certain context. Therefore, this paper would be a great asset and would be useful for those interested in studying a foreign language from a practical aspect, i.e. individuals that develop language programs, foreign language teachers as well as foreign language learners.

\subsection{Literature Review}

There has been an ever-growing focus and interest in the pragmatics of a foreign language, i.e. the pragmatics applied to foreign language teaching and learning, cross-cultural communication and interlanguage pragmatics and speech acts in the past several decades. There are also a large number of studies and research on pragmatics and language learning strategies in different contexts. However, it is important to state that these studies do not refer to the English teaching and learning process in Macedonia but elsewhere. Still, they are important for the Macedonian education system as they provide best practices and recommendations that could be used to improve the language teaching and learning process and contribute to the development of students' communicative competence in Macedonia.

\subsubsection{Pragmatics and Pragmatic Competence}

Pragmatics mainly deals with what is beyond the dictionary meanings of words and utterances. In other words, it is about what is actually meant by an utterance based on the norms and conventions of a particular society or the context in which certain conversation takes place. Therefore, having a good command of the conventions enables the speaker to establish and maintain effective and appropriate communication as well as to understand each other clearly (Yule, 1996). This ability is generally referred to as pragmatic competence (Takkaç, 2016).

Following the shift in which the emphasis in language pedagogy changed from the linguistic-based to communicative-based purposes, the impact and status of pragmatic competence has gradually increased in educational circles. Moreover, the curricula and relevant syllabi in the Macedonian education are focused on the development of both verbal and written communication competences in a foreign language supplemented by reading, sociocultural and intercultural competences.

A lot of research and studies on pragmatic competence have been conducted so far, which offer a clearer picture of the role of pragmatic competence and its relation to different factors in language education. Namely, Bardovi-Harlig \& Dörnyei (1998), among others, analysed the impact of the learning environment on pragmatic competence focusing on a comparison of ESL and EFL contexts for language learning. Most of the studies demonstrated that it is better to learn a target language in ESL contexts rather than in EFL ones, particularly in terms of the development of pragmatic competence, due to learners' exposure to the appropriate usages of target forms in their natural setting (Takkaç, 2016).

\subsubsection{Interlanguage Pragmatics and Cross-Cultural Communication}

Interlanguage pragmatics (ILP) has gained more attention among pragmatics researchers. It is defined as "the study of nonnative speakers' use and acquisition of L2 pragmatic knowledge" (Kasper, 1996, p.145). It deals with both pragmatic competence and language performance of second or foreign language learners $(\mathrm{Ji}, 2008)$ and the development of pragmatic competence by non-native speakers.

Communication is becoming increasingly cross-cultural in many contexts as very often the people involved in the communication have different cultures, different mother tongues and different norms and values. Both cross-cultural and intercultural pragmatics are interested in exploring interactions between diverse speakers in order to come to a common understanding in relation to the roles and functions of language and communication in a world-wide communication network (Pütz \& Neff-van Aertselaer, 2008).

\subsubsection{Speech Act Theory}

Speech act theory plays a core role in the field of pragmatics. It was initially proposed in the 1950s and widely discussed in the 1960s and 1970s by philosophers, such as Wittgenstein, Austin and Searle. Wittgenstein (1953) made a significant contribution to the field of pragmatics; Austin (1962), as a founder of the speech act theory, is regarded as the father of pragmatics (Mott, 2003), and the speech act theory was later elaborated by Searle (1969, 1971, 1975, 1976, 1979). This theory reflects a routinized language behavior that helps learning in the sense that much of what is said is predictable (Cohen, 1996).

Austin's speech act theory was built on the belief that speakers do not only use language to say things, but to do things as well. Hence, utterances are regarded as speech acts. Austin (1962) introduced the "doctrine of 
illocutionary forces" that focuses on the performative linguistic function in which speech is regarded as action. Hence, Austin classifies speech acts in three categories. The first category is the locutionary act as an act of constructing an utterance by following grammars and vocalizing the sentence. It is the utterance of a sentence that determines sense and reference. The second category is the illocutionary act. In this act, one actually performs an act in uttering the sentence. The third category is the perlocutionary act; an act of bringing about effects on the audience by means of uttering the sentences - such effects being special to the circumstances of utterance (Levinson, 1983).

Searle developed Austin's speech act theory further and focused on the illocutionary acts performed by the speaker.

He offers a new categorization of illocutionary force based on relatively clear principles of distinction, as follows:

a) assertives - they commit the speaker to the truth of the expressed proposition (paradigm cases: asserting, concluding, etc.)

b) directives - they are attempts by the speaker to get the addressee to do something (paradigm cases: requesting, questioning)

c) commissives - they commit the speaker to some future course of action (paradigm cases: promising, threatening, offering)

d) expressives - they express a psychological state (paradigm cases: thanking, apologising, welcoming, congratulating)

e) declarations - they affect immediate changes in the institutional state of affairs and tend to rely on elaborate extra-linguistic institutions (paradigm cases: excommunicating, declaring war, christening, firing from employment) (Levinson, 1983).

The current study has explored the speech act of complimenting that belongs to assertives. Thus, high school English language students' levels of pragmatics in Macedonia are examined for the purpose of understanding students' levels of communicative competence.

\section{Method}

\subsection{Design of the Study}

This study is designed as a case study conducted in a high school in Bitola, Macedonia. A case study research allows exploration of complex issues. It is recognized as a tool in many social science studies and it becomes more and more important when issues with regard to education (Gülseçen \& Kubat, 2006), sociology (Grassel \& Schirmer, 2006) and community-based problems (Johnson, 2006), such as poverty, unemployment, drug addiction, etc. are raised.

There are three specific types of case studies: exploratory, explanatory and descriptive (Yin, 2003). The present study was exploratory as it was aimed at exploring English pragmatics of Macedonian high school students as learners of English in Macedonian context as well as to explore the issues students had in learning pragmatics.

Both quantitative and qualitative methods were applied in this study and data were collected and analysed by using quantitative techniques within a qualitative research framework.

The study was conducted in a high school in Macedonia as the curriculum for English as the first foreign language focuses on the development of students' language and their communicative competence in English.

\subsection{Participants}

The participants in this study were Macedonian high school students in the I, II, III and IV school year in the secondary education in Macedonia as learners of English in Macedonian context. Data were collected during the second semester of their studies in the relevant school year. This allowed them to adapt to the curricula for secondary education and acquire enough English language proficiency to participate in this research.

The students were invited to participate in this study voluntarily and anonymously. They were fully informed of the aims and significance of the study by the researcher before the commencement of the study, and made their decisions independently as to whether to participate or not. They were also informed of their right to withdraw from the study at any time.

A total of 240 students (60 students from each school year) were invited to complete the questionnaire and the DCTs on a voluntary basis. 


\subsection{Data Collection}

Quantitative data were collected from the closed-ended and open-ended questions included in the questionnaire and the closed-ended questions in the DCTs. The data collection procedures took place in the following manner. First, approval was sought from the Director of the General High School Josip Broz Tito in Bitola, Macedonia. Then, data collection based on a questionnaire and DCTs took place between 5-15 December 2016.

In order not to disturb students' study routines, the study was conducted outside the regular teaching hours. The students needed 30 minutes to complete the questionnaire and the DCTs, which was conducted with each of the students individually.

\subsection{Data Analysis}

The data analysis process is aimed at obtaining information that lies behind the surface of the content of the data. The raw quantitative data collected from the questionnaire and the DCTs were used for quantitative analysis.

The following sections describe the research data collection and analysis methods in this study.

\subsection{Questionnaire}

The questionnaire is one of the quantitative data collection instruments that can obtain a broad perspective from the research subjects (Denscombe, 2007).

The questionnaire employed for this study was in English and consisted of closed-ended questions that offered multiple choice answers, Likert-type questions that offered 5-point multiple choice answers aimed at gathering demographic information on the students as well as their views on and perceptions of pragmatic knowledge and language learning strategies, and consisted of two sections.

The first section of the questionnaire consisted of 8 questions, 5 of which were closed-ended and 3 were open-ended questions. The information gathered was analyzed to explore the implications of the relationship between the demographic data and students' views and perceptions of pragmatics in high school English language learning in Macedonian context.

The second section consisted of two parts. Part A consisted of 10 Likert-type questions with 5-point multiple choice answers ranging from: $1=$ strongly disagree, $2=$ disagree, $3=$ neutral, $4=$ agree and $5=$ strongly agree. Part B consisted of 6 closed-ended questions with multiple choice answers. This section was aimed at producing results on the students' views and perceptions of pragmatics.

The collected data were grouped and statistically transformed in tables and charts reporting figures and percentages. The results were textually described as well.

\subsection{Discourse Completion Tasks (DCTs)}

DCTs have become one of the most commonly used research instruments in pragmatic research, first employed by Blum-Kulka (1982).

Written Discourse Completion Tasks (WDCTs) were used in this study whereby students were requested to read a written description of a situation and then asked to choose the most appropriate answer of what they would say in that situation by choosing one of the offered multiple choice answers. WDCTs do not ask participants to interact conversationally but only to choose the answer that is the most appropriate according to them. To get an insight in the adoption and expression of the speech acts by the Macedonian learners of English, this study focused on the speech act of complimenting expressed by the Macedonian learners of English as their first foreign language. Three situations were provided for this speech act, as the most common situations in which students can find themselves, although it is hard to argue that the answers chosen by the students correspond to what they would say in natural, spontaneous speech.

DCTs in this study were aimed at collecting data about students' pragmatic knowledge, levels of pragmatic competence and their strategies in using English. As mentioned above, 240 students in total, i.e. 60 students per each school year, completed the DCTs.

The data collected were reported in the form of figures and percentages.

\section{Results}

\subsection{Questionnaire Data}

This section reports on the questionnaire findings with respect to the three research questions:

1) What are the Macedonian high school English language students' views on and perceptions of pragmatics in their English learning process? 
2) To what extent do high school English language students in Macedonia focus on their pragmatic knowledge in their English learning? What are their levels of pragmatic competence?

\section{3) How do high school English language students apply their language learning strategies in the pragmatics} and English learning process?

The quantitative data gathered from 240 participants' responses to the questionnaire were analysed by means of descriptive statistics and they are hereby presented in tables and charts.

\subsubsection{Demographic Data}

In the first section of the questionnaire, students provided their personal demographic data.

Hence, $36.67 \%$ of the students were males and $63.33 \%$ were females; all students, i.e. $100 \%$ of the students in the first school year were aged 15 years, $100 \%$ of the students in the second school year were aged 16 years, $100 \%$ of the students in the third school year were aged 17 years and $100 \%$ of the students in the first school year were aged 18 years. 60 students from each school year participated in the study, i.e. a total number of 240 students from all four school years as mentioned above. The question about the students' major was not answered by anyone, which may indicate that the students have not understood this question. Our assumption is that the students would have understood the question if it had been directly and literally translated from Macedonian into English, which would sound like this: "What is your main subject at school?", while the question posed in the questionnaire was "What is your major?", since it is a more appropriate translation according to the English jargon used in this context. As regards the question, only 3 students had learned English for less than six years, whereas $74.58 \%$ had learned English for six to ten years and $24.17 \%$ for more than ten years. Only $12.08 \%$ of the students had learned English in an English-speaking country, and $60.42 \%$ had visited an English-speaking country for other purposes (private visit, work, etc.). $70.83 \%$ of the students had had a native English-speaking teacher. Table 1 shows a summary of these demographic data of the students who participated in the questionnaire.

Table 1. Demographic data

\begin{tabular}{|c|c|c|c|c|c|c|c|c|c|c|c|}
\hline \multirow{2}{*}{ No. } & \multirow{2}{*}{ Items } & \multicolumn{5}{|c|}{ Number } & \multicolumn{5}{|c|}{ Percentage } \\
\hline & & $\mathbf{I}$ & II & III & IV & Total & $\mathbf{I}$ & II & III & IV & Total \\
\hline \multirow[t]{3}{*}{1.} & Gender & & & & & & & & & & \\
\hline & Male & 25 & 23 & 14 & 26 & 88 & 41.67 & 38.33 & 23.33 & 43.33 & 36.67 \\
\hline & Female & 35 & 37 & 46 & 34 & 152 & 58.33 & 61.67 & 76.67 & 56.67 & 63.33 \\
\hline \multirow[t]{5}{*}{2.} & Age & & & & & & & & & & \\
\hline & 15 & 60 & & & & 60 & 100 & & & & 100 \\
\hline & 16 & & 60 & & & 60 & & 100 & & & 100 \\
\hline & 17 & & & 60 & & 60 & & & 100 & & 100 \\
\hline & 18 & & & & 60 & 60 & & & & 100 & 100 \\
\hline \multirow[t]{5}{*}{3.} & School year curren & endi & & & & & & & & & \\
\hline & I & 60 & & & & 60 & 100 & & & & 100 \\
\hline & II & & 60 & & & 60 & & 100 & & & 100 \\
\hline & III & & & 60 & & 60 & & & 100 & & 100 \\
\hline & IV & & & & 60 & 60 & & & & 100 & 100 \\
\hline \multirow[t]{4}{*}{4.} & Length of English 1 & ng pe & & & & & & & & & \\
\hline & Less than 6 years & 2 & / & I & 1 & 3 & 3.33 & l & / & 1.67 & 1.25 \\
\hline & $6-10$ years & 43 & 46 & 54 & 36 & 179 & 71.67 & 76.67 & 90 & 60 & 74.58 \\
\hline & More than 10 years & 15 & 14 & 6 & 23 & 58 & 25 & 23.33 & 10 & 38.33 & 24.17 \\
\hline \multirow[t]{3}{*}{5.} & Language learning & ienc & an $\mathbf{E}$ & lish-s & akin & untry & & & & & \\
\hline & Yes & 10 & 7 & 6 & 6 & 29 & 16.67 & 11.67 & 10 & 10 & 12.08 \\
\hline & No & 50 & 53 & 54 & 54 & 211 & 83.33 & 88.33 & 90 & 90 & 87.92 \\
\hline \multirow[t]{3}{*}{6.} & Visit to an English- & ing & ntry & othe & urp & & & & & & \\
\hline & Yes & 28 & 22 & 23 & 22 & 95 & 46.67 & 36.67 & 38.33 & 36.67 & 39.58 \\
\hline & No & 32 & 38 & 37 & 38 & 145 & 53.33 & 63.33 & 61.67 & 63.33 & 60.42 \\
\hline \multirow[t]{3}{*}{7.} & Have had a native $I$ & h-sp & ing $t$ & her & & & & & & & \\
\hline & Yes & 19 & 26 & 12 & 13 & 70 & 31.67 & 43.33 & 20 & 21.67 & 29.17 \\
\hline & No & 41 & 34 & 48 & 47 & 170 & 68.33 & 56.67 & 80 & 78.33 & 70.83 \\
\hline
\end{tabular}


3.1.2 Students' Views on and Perceptions of Pragmatics in High School English Learning and Teaching in Macedonia

This section reports on the questionnaire findings concerning the research question: What are the Macedonian high school English language students' views on and perceptions of pragmatics in their English learning process?

Concerning the relationship between the linguistic and pragmatic knowledge, based on students' answers, it is important for both the linguistic and pragmatic knowledge to be acquired in a balanced way in the language learning process (see Table 2). More than $80 \%$ of the students agreed that learning English grammar, vocabulary and pronunciation meant learning English, while only 3.34\% of the students believed that they needed to acquire other knowledge besides the linguistic knowledge. What is interesting is that more than $10 \%$ of the students could not decide whether learning English grammar, vocabulary and pronunciation meant learning English. More than $80 \%$ of the students believed that the knowledge of how to use the language (pragmatic knowledge) was as important as linguistic knowledge in the language learning process. Similarly, more than $3 \%$ disagreed on this question, while more than $15 \%$ of the students were neutral when it comes to comparing the importance of pragmatic and linguistic knowledge.

Table 2. Students' views on and perceptions of linguistic and pragmatic knowledge

\begin{tabular}{|c|c|c|c|c|c|c|c|c|c|c|c|}
\hline \multirow[t]{2}{*}{ No. } & \multirow[t]{2}{*}{ Item. } & \multicolumn{5}{|c|}{ Numbers } & \multicolumn{5}{|c|}{ Percentage } \\
\hline & & $\mathbf{I}$ & II & III & IV & Total & I & II & III & IV & Total \\
\hline 1. & \multicolumn{11}{|c|}{ Q9. I believe learning English means learning English grammar, vocabulary, and pronunciation. } \\
\hline SD & & / & / & 1 & / & 1 & / & 1 & 1.67 & 1 & 0.42 \\
\hline D & & I & I & 1 & 6 & 7 & I & I & 1.67 & 10 & 2.92 \\
\hline $\mathbf{N}$ & & 8 & 6 & 8 & 10 & 32 & 13.33 & 10 & 13.33 & 16.67 & 13.33 \\
\hline $\mathbf{A}$ & & 28 & 28 & 32 & 22 & 110 & 46.67 & 46.67 & 53.33 & 36.67 & 45.83 \\
\hline SA & & 24 & 26 & 18 & 22 & 90 & 40 & 40 & 30 & 36.67 & 37.5 \\
\hline 2. & \multicolumn{11}{|c|}{$\begin{array}{l}\text { Q10. I think that the knowledge of how to use the language is as important as the linguistic knowledge (e.g. vocabulary } \\
\text { and grammar). }\end{array}$} \\
\hline SD & & 1 & 1 & I & 4 & 4 & 1 & 1 & I & 6.67 & 1.67 \\
\hline D & & / & I & 1 & 4 & 5 & I & / & 1.67 & 6.67 & 2.08 \\
\hline $\mathbf{N}$ & & 9 & 12 & 6 & 10 & 37 & 15 & 20 & 10 & 16.67 & 15.42 \\
\hline $\mathbf{A}$ & & 30 & 20 & 24 & 22 & 96 & 50 & 33.33 & 40 & 36.67 & 40 \\
\hline SA & & 21 & 28 & 29 & 20 & 98 & 35 & 46.67 & 48.33 & 33.33 & 40.83 \\
\hline
\end{tabular}

Note. $\mathrm{SD}=$ Strongly Disagree, $\mathrm{D}=$ Disagree, $\mathrm{N}=$ Neutral, $\mathrm{A}=$ Agree, $\mathrm{ST}=$ Strongly Agree.

Based on the data presented above, it appears that students recognized that pragmatic knowledge is equally important as linguistic knowledge in the language learning process.

When asked to state what kind of ability students want to gain most in their English language learning, around $74 \%$ of them indicated that they wanted to acquire the ability to communicate with people. Around $13 \%$ of the students stated they want to gain the ability to read materials related to their major, which is rather odd taking into account that they didn't answer the question about what their major was. Then, more than $8 \%$ answered that they wanted to obtain the ability to translate, and only $5 \%$ of the students indicated that they preferred to gain the ability to do well in English examinations (see Figure 1). 


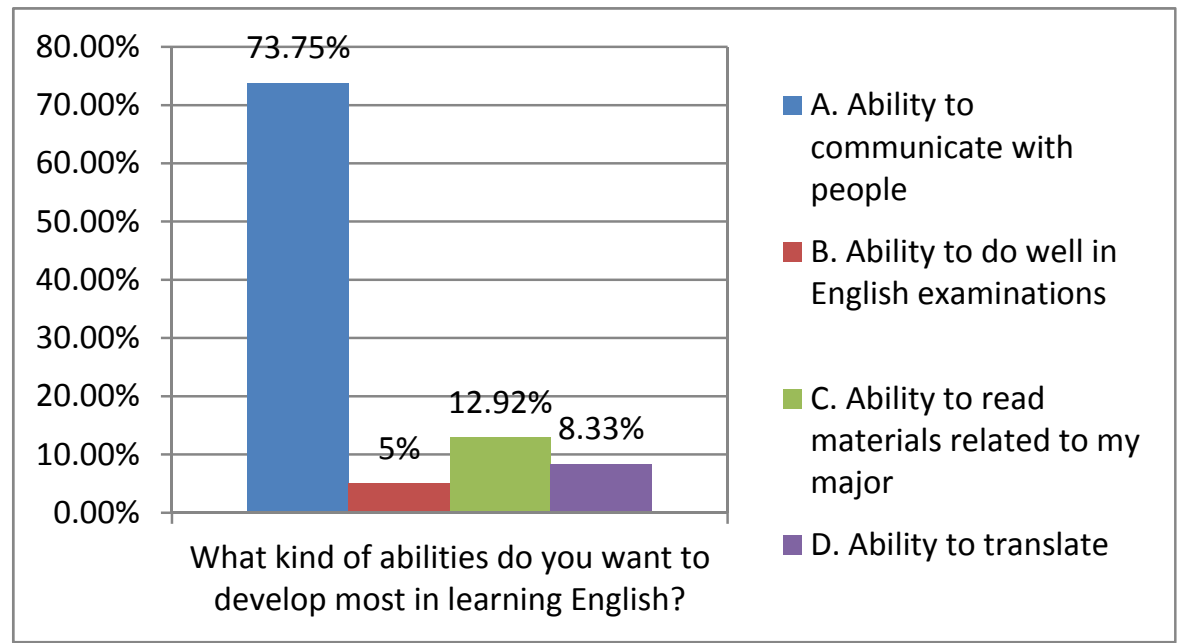

Figure 1. Ability students want to gain most in English

More than $80 \%$ of the students stated that they wished to speak like native English speakers and imitate their pronunciation and intonation, which shows that the development of communication competence seems to be the students' learning aim. $85 \%$ of the students indicated to show admiration to people who can communicate with others in English fluently and accurately. Around 90\% of them stated that their main reason for learning English is not to pass the exam.

Table 3. Students' views on English language learning outcomes

\begin{tabular}{|c|c|c|c|c|c|c|c|c|c|c|c|}
\hline \multirow{2}{*}{ No. } & \multirow{2}{*}{ Item. } & \multicolumn{5}{|c|}{ Numbers } & \multicolumn{5}{|c|}{ Percentage } \\
\hline & & $\mathbf{I}$ & II & III & IV & Total & I & II & III & IV & Total \\
\hline 1. & \multicolumn{11}{|c|}{ Q11. The main reason why I need to learn English is to pass the exam. } \\
\hline SD & & 24 & 40 & 44 & 45 & 153 & 40 & 66.67 & 73.33 & 75 & 63.75 \\
\hline D & & 29 & 14 & 14 & 5 & 62 & 48.33 & 23.33 & 23.33 & 8.33 & 25.83 \\
\hline $\mathbf{N}$ & & 7 & 6 & / & 3 & 16 & 11.67 & 10 & 1 & 5 & 6.67 \\
\hline $\mathbf{A}$ & & / & 1 & 1 & 3 & 4 & I & / & 1.67 & 5 & 1.67 \\
\hline SA & & 1 & I & 1 & 4 & 5 & 1 & / & 1.67 & 6.67 & 2.08 \\
\hline 2. & \multicolumn{11}{|c|}{ Q14. I admire the people who can communicate with others in English fluently and accurately. } \\
\hline SD & & 1 & / & 1 & / & 1 & / & / & 1.67 & / & 0.42 \\
\hline D & & / & / & 1 & 4 & 5 & / & / & 1.67 & 6.67 & 2.08 \\
\hline $\mathbf{N}$ & & 11 & 7 & 4 & 8 & 30 & 18.33 & 11.67 & 6.67 & 13.33 & 12.50 \\
\hline $\mathbf{A}$ & & 22 & 20 & 19 & 15 & 76 & 36.67 & 33.33 & 31.67 & 25 & 31.67 \\
\hline $\mathbf{S A}$ & & 27 & 33 & 35 & 33 & 128 & 45 & 55 & 58.33 & 55 & 53.33 \\
\hline 3. & \multicolumn{11}{|c|}{ Q19. I wish to speak like native English speakers and imitate their pronunciation and intonation. } \\
\hline SD & & 1 & / & 1 & 4 & 5 & / & / & 1.67 & 6.67 & 2.08 \\
\hline D & & 3 & 5 & / & / & 8 & 5 & 8.33 & / & / & 3.33 \\
\hline $\mathbf{N}$ & & 9 & 10 & 1 & 12 & 32 & 15 & 16.67 & 1.67 & 20 & 13.33 \\
\hline A & & 8 & 15 & 16 & 13 & 52 & 13.33 & 25 & 26.67 & 21.67 & 21.67 \\
\hline $\mathbf{S A}$ & & 40 & 30 & 42 & 31 & 143 & 66.67 & 50 & 70 & 51.67 & 59.58 \\
\hline
\end{tabular}

Note. $\mathrm{SD}=$ Strongly Disagree, $\mathrm{D}=$ Disagree, $\mathrm{N}=$ Neutral, $\mathrm{A}=$ Agree, $\mathrm{ST}=$ Strongly Agree.

There are different kinds of English that students want to learn to use as a tool in communication based on the society and classroom teaching. As indicated by the responses to Question 20, students show somewhat the same interest to learn American and British English, i.e. around 50\% of the students would like to learn British English and $47 \%$ would like to learn American English. What is more interesting is to see that more than $3 \%$ of the students want to learn the so called form of 'Macedonian English', which is not an official variety of the English language but refers to literal translation of the Macedonian words in English. This leads to the conclusion that this small percentage of students probably did not fully understand this question (see Figure 2). 


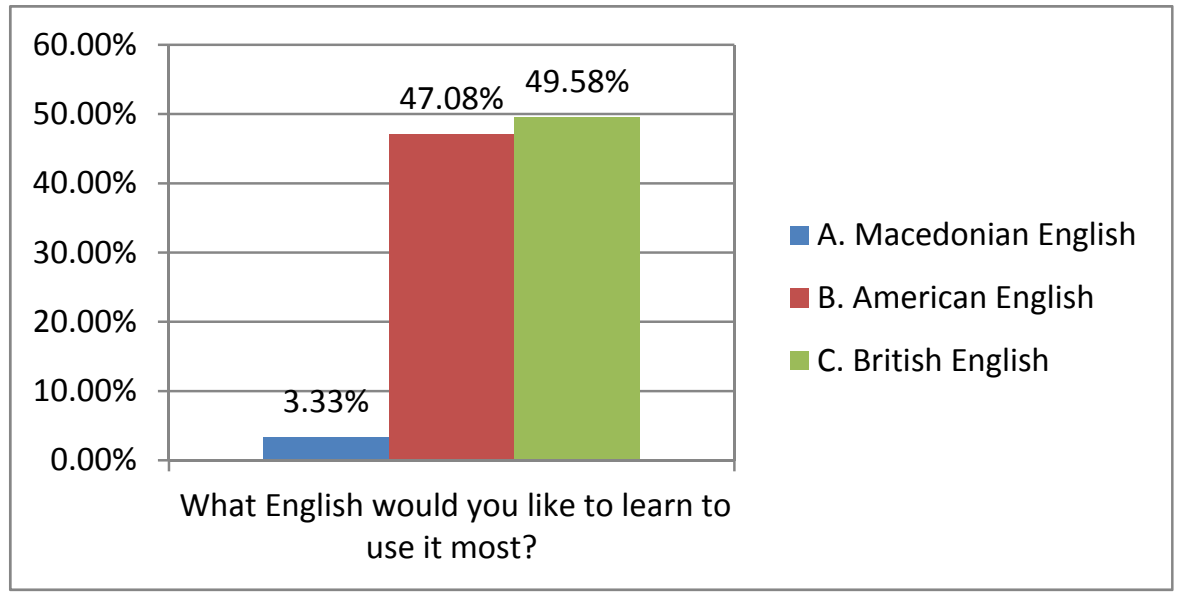

Figure 2. Types of English students want to learn to use

Table 4 indicates students' views on communicative language teaching and practice in high school English classrooms and includes responses to Questions 13, 15 and 17 from the questionnaire. Around $68 \%$ of the students stated that they wanted their English class activities to focus on CLT and practice, with grammar explained when necessary. Around $57 \%$ of them indicated that language teachers should teach students how to communicate with people and how to use English appropriately in the classroom instead of focusing on grammar and vocabulary. This is confirmed by the results showing that about $85 \%$ of the students do not consider communicative activities in the English class were a waste of time (see Table 4).

Table 4. Students' views on communicative language teaching and practice

\begin{tabular}{|c|c|c|c|c|c|c|c|c|c|c|c|}
\hline \multirow{2}{*}{ No. } & \multirow{2}{*}{ Item. } & \multicolumn{5}{|c|}{ Numbers } & \multicolumn{5}{|c|}{ Percentage } \\
\hline & & $\mathbf{I}$ & II & III & IV & Total & $\mathbf{I}$ & II & III & IV & Total \\
\hline 1. & \multicolumn{11}{|c|}{ Q13. Communicative activities are a waste of time in the English class. } \\
\hline SD & & 32 & 40 & 40 & 30 & 142 & 53.33 & 66.67 & 66.67 & 50 & 59.17 \\
\hline D & & 15 & 16 & 14 & 16 & 61 & 25 & 26.67 & 23.33 & 26.67 & 25.42 \\
\hline $\mathbf{N}$ & & 7 & 4 & 2 & 9 & 22 & 11.67 & 6.67 & 3.33 & 15 & 9.17 \\
\hline $\mathbf{A}$ & & 6 & / & 4 & 5 & 15 & 10 & I & 6.67 & 8.33 & 6.25 \\
\hline SA & & I & I & I & I & 1 & I & I & 1 & 1 & I \\
\hline 2. & \multicolumn{11}{|c|}{$\begin{array}{l}\text { Q15. I think teachers should teach us how to communicate with people and how to use English appropriately in the } \\
\text { classroom instead of focusing on grammar and vocabulary. }\end{array}$} \\
\hline SD & & 5 & I & 1 & I & 5 & 8.33 & 1 & 1 & I & 2.08 \\
\hline D & & 8 & 8 & 3 & 5 & 24 & 13.33 & 13.33 & 5 & 8.33 & 10 \\
\hline $\mathbf{N}$ & & 17 & 24 & 18 & 16 & 75 & 28.33 & 40 & 30 & 26.67 & 31.25 \\
\hline A & & 13 & 20 & 16 & 24 & 73 & 21.67 & 33.33 & 26.67 & 40 & 30.42 \\
\hline SA & & 17 & 8 & 23 & 15 & 63 & 28.33 & 13.33 & 38.33 & 25 & 26.25 \\
\hline 3. & \multicolumn{11}{|c|}{$\begin{array}{l}\text { Q17. I prefer my English class to be focused on communicative language teaching and practice, with grammar explained } \\
\text { when necessary. }\end{array}$} \\
\hline SD & & 1 & I & 1 & 1 & I & 1 & 1 & 1 & 1 & 1 \\
\hline D & & 4 & 3 & / & 10 & 17 & 6.67 & 5 & / & 16.67 & 7.08 \\
\hline $\mathbf{N}$ & & 13 & 24 & 9 & 14 & 60 & 21.67 & 40 & 15 & 23.33 & 25 \\
\hline A & & 24 & 14 & 32 & 23 & 93 & 40 & 23.33 & 53.33 & 38.33 & 38.75 \\
\hline SA & & 19 & 19 & 19 & 13 & 70 & 31.67 & 31.67 & 31.67 & 21.67 & 29.17 \\
\hline
\end{tabular}

Regarding the pragmatically oriented tasks that English teachers most often used in the classroom teaching in high schools, $47 \%$ of the students stated that pair work is the most often used task, about $37 \%$ of them indicated group discussion, whereas role play (almost $8.5 \%$ ) and debate (about $8 \%$ ) were used with a similar frequency in the classroom (see Figure 3). 


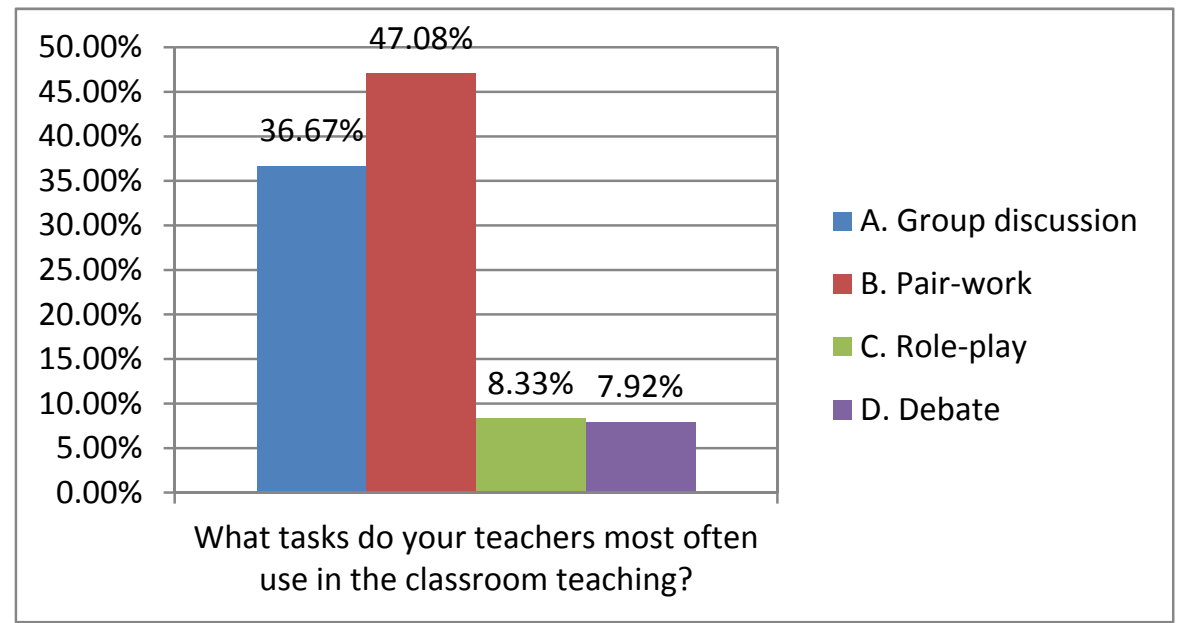

Figure 3. Pragmatically-oriented tasks most often used in classroom teaching

Regarding classroom learning and teaching, around $65 \%$ of the students indicated their like of grammar and vocabulary explanation and sentence drills in their English class, while only about $10 \%$ of them indicated their dislike. Around $35 \%$ of the students neither expressed their like nor their dislike as they were neutral. In terms of the tasks applied in the classroom, more than $70 \%$ of the students believed that the tasks applied provided them with knowledge and skills to improve their ability to use English appropriately. Only half of the students, i.e. around 53\%, responded that the high school English textbooks used in the classroom provided them with knowledge and skills to improve their ability to use English appropriately.

Table 5. Students' views on classroom language teaching and practice

\begin{tabular}{|c|c|c|c|c|c|c|c|c|c|c|c|}
\hline \multirow[t]{2}{*}{ No. } & \multirow[t]{2}{*}{ Item. } & \multicolumn{5}{|c|}{ Numbers } & \multicolumn{5}{|c|}{ Percentage } \\
\hline & & I & II & III & IV & Total & I & II & III & IV & Total \\
\hline 1. & \multicolumn{11}{|c|}{$\begin{array}{l}\text { Q12. High school English textbooks provide a lot of information on culture, conversation rules, usage, and how to use } \\
\text { English correctly. }\end{array}$} \\
\hline SD & & 1 & 1 & 1 & 5 & 5 & 1 & 1 & 1 & 8.33 & 2.08 \\
\hline D & & 7 & / & 6 & 10 & 23 & 11.67 & / & 10 & 16.67 & 9.58 \\
\hline $\mathbf{N}$ & & 20 & 21 & 21 & 23 & 85 & 33.33 & 35 & 35 & 38.33 & 35.42 \\
\hline A & & 18 & 26 & 25 & 15 & 84 & 30 & 43.33 & 41.67 & 25 & 35 \\
\hline SA & & 15 & 13 & 8 & 7 & 43 & 25 & 21.67 & 13.33 & 11.67 & 17.92 \\
\hline 2. & \multicolumn{11}{|c|}{$\begin{array}{l}\text { Q16. The tasks given to us in the English class provide me with knowledge and skills to improve my ability to use English } \\
\text { appropriately. }\end{array}$} \\
\hline SD & & 1 & I & I & 2 & 2 & 1 & 1 & 1 & 3.33 & 0.83 \\
\hline D & & 1 & / & 2 & 10 & 12 & I & / & 3.33 & 16.67 & 5 \\
\hline $\mathbf{N}$ & & 10 & 23 & 18 & 17 & 68 & 16.67 & 38.33 & 30 & 28.33 & 28.33 \\
\hline $\mathbf{A}$ & & 35 & 29 & 27 & 28 & 119 & 58.33 & 48.33 & 45 & 46.67 & 55.58 \\
\hline SA & & 15 & 8 & 13 & 3 & 38 & 25 & 13.33 & 21.67 & 5 & 15.83 \\
\hline 3. & \multicolumn{11}{|c|}{ Q18. I like grammar and vocabulary explanation, and sentence drills in my English class. } \\
\hline SD & & 1 & / & / & 1 & 1 & 1 & 1 & / & / & / \\
\hline D & & 7 & 5 & 4 & 7 & 23 & 11.67 & 8.33 & 6.67 & 11.67 & 9.58 \\
\hline $\mathbf{N}$ & & 20 & 10 & 32 & 19 & 81 & 33.33 & 16.67 & 53.33 & 31.67 & 33.75 \\
\hline $\mathbf{A}$ & & 23 & 15 & 21 & 24 & 83 & 38.33 & 25 & 35 & 40 & 34.58 \\
\hline SA & & 10 & 30 & 3 & 10 & 53 & 16.67 & 50 & 5 & 16.67 & 22.08 \\
\hline
\end{tabular}

\subsubsection{Students' Perceptions and Practice of Language Learning Strategies}

This section reports on the questionnaire findings concerning the third research question: How do high school English language students apply their language learning strategies in the pragmatics and English learning process?

When asked to choose the most effective way of learning English, nearly $60 \%$ of the students indicated conversations and discussions in English in the classroom as their most preferred way of language learning. 
Around $20 \%$ of the students chose the self-studying and self-evaluation method, around $12 \%$ of them listed the method of memorising vocabularies and reciting texts and about $10 \%$ of them indicated the method of doing sentence drills and translation exercises (see Figure 4).

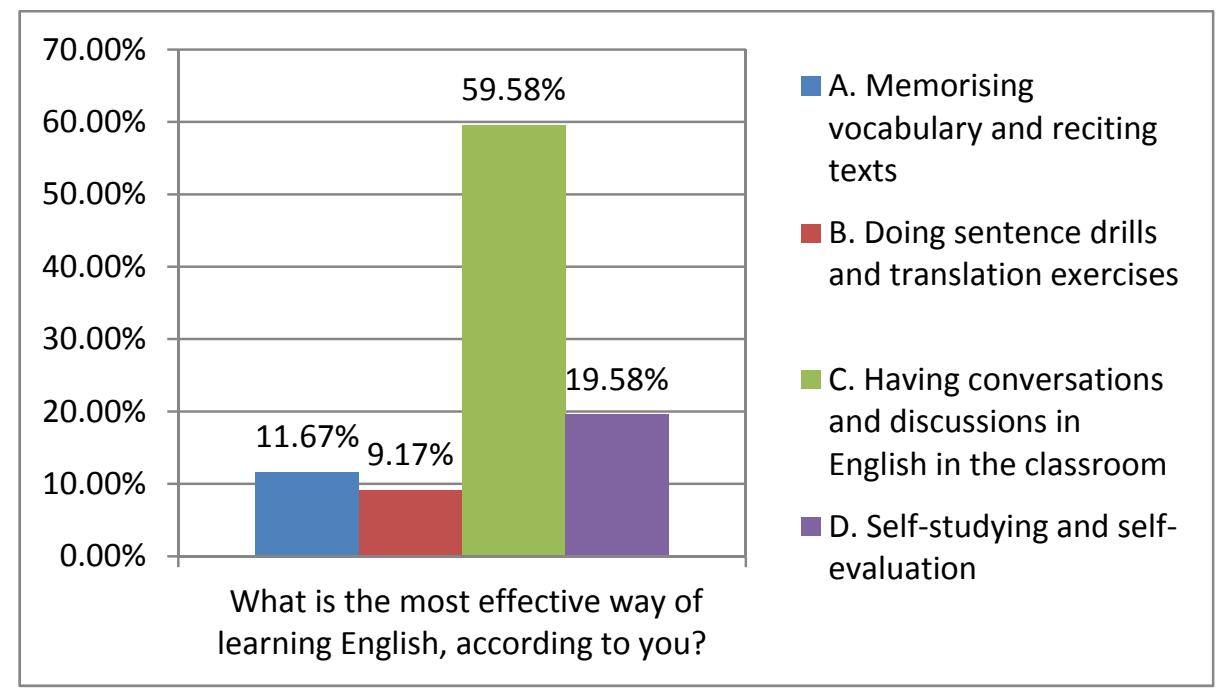

Figure 4. Most effective way of learning English

There is a variety of activities or methods applied in the English language learning process that could help students acquire language knowledge and language competence in an effective manner. Figure 5 below shows students' preference of ways to get information about the use of English. Nearly $53 \%$ of the students preferred listening to radio programs/dialogues and watching TV programs/videos in English. About 23\% of them wanted to get information from teachers' explanation and less than $17 \%$ preferred to learn by themselves. The least preferred way of getting information about the use of English was the classroom discussion as indicated by less than $9 \%$ of the students.

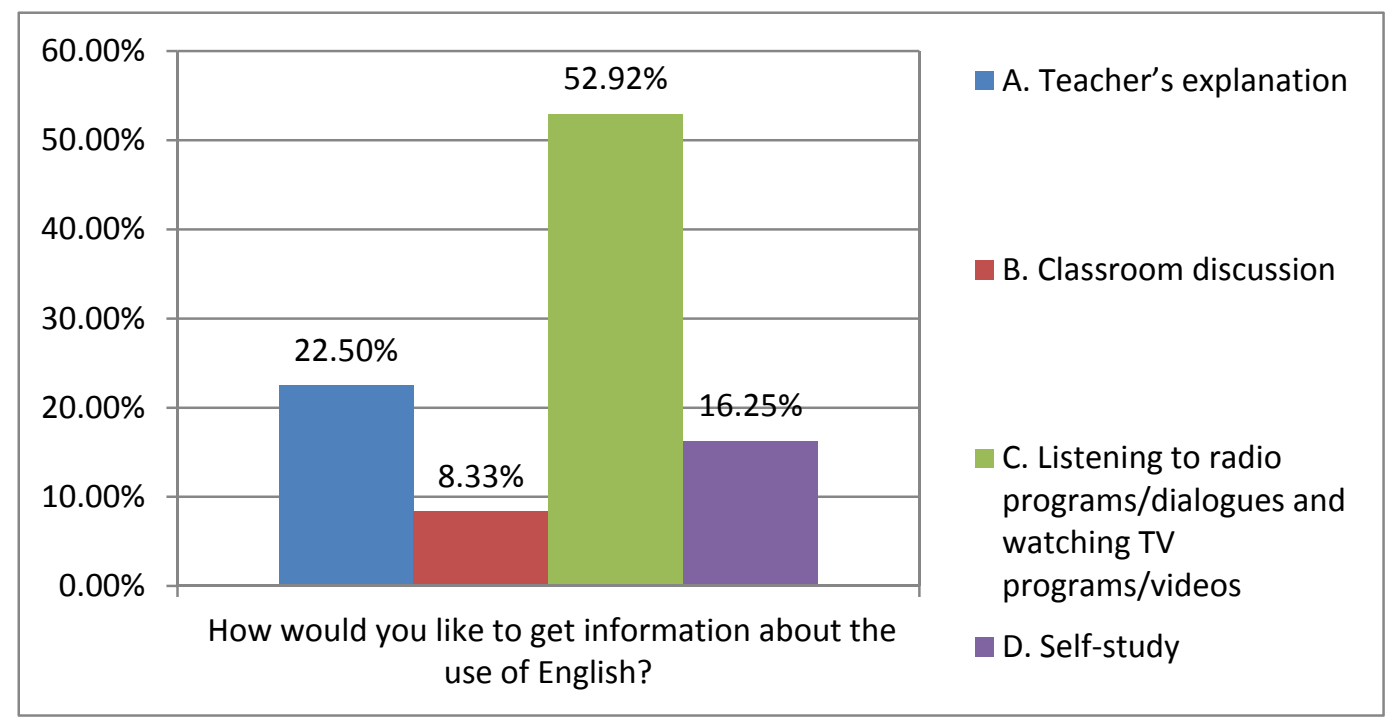

Figure 5. Students' preferable way to get information about the use of English

Resolving difficulties that might appear for language learners in the language learning process in a proficient manner is essential as this would help language learners acquire the required language competence. Less than 50\% of the students stated that they encountered difficulties by looking up a dictionary or trying to find the answer on the Internet. Around $24 \%$ of them indicated that they were trying to solve the problem on their own, whereas $17 \%$ of them indicated that they would ask their English teacher or a native speaker to help them. Around $12 \%$ of the 
students preferred discussing and working with their classmates (see Figure 6).

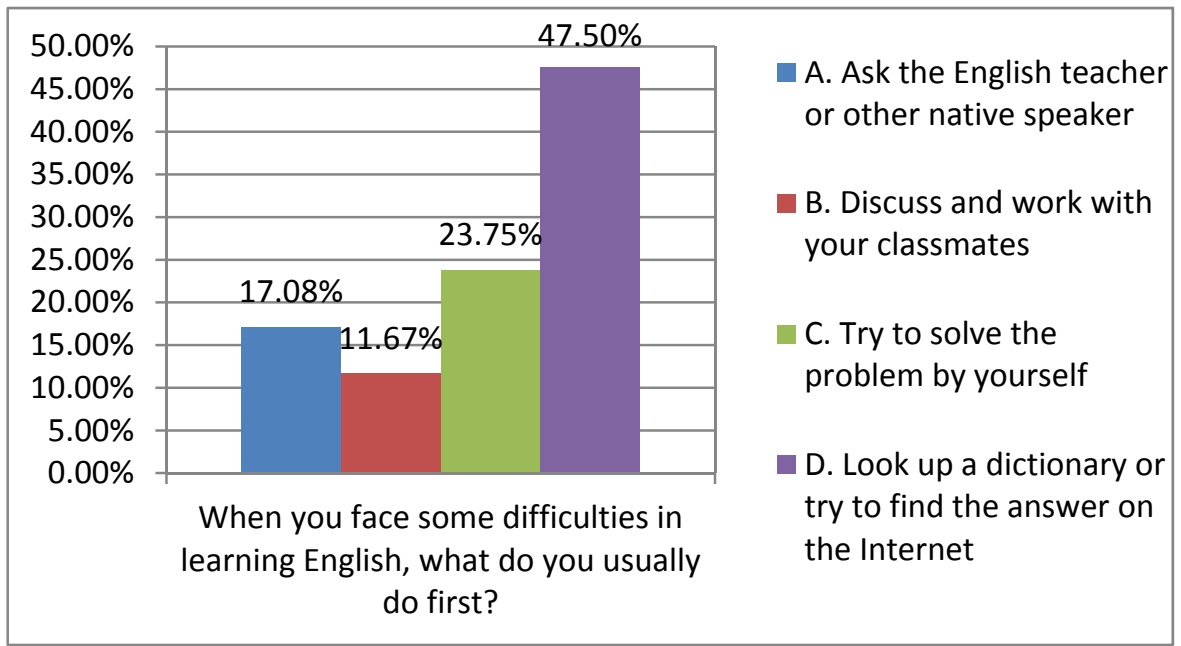

Figure 6. Ways of solving difficulties in the English language learning process

As it can be seen from the results presented above, students apply various language learning strategies in the process of acquiring English as their first foreign language.

Another way to understand students' English pragmatic knowledge and competence is by using DCTs. The following section details and recounts the DCT data.

\subsection{Discourse Completion Tasks Data}

This section reports the results related to the second research question: To what extent do high school English language students in Macedonia focus on their pragmatic knowledge in their English language learning? What are their levels of pragmatic competence?, and the third research question: How do high school English language students apply their language learning strategies in the pragmatics and English language learning process? DCTs used in this study required students to read a written description of a speech situation and then provide their response to each situation by choosing the answer that is most appropriate according to them. The current DCTs covered the speech act of complimenting, which is examined through three different situations.

\subsubsection{Compliment Responses}

The speech act of complimenting is a very common expressive speech act according to Searle (1975) which can be used to anyone, every day and in many circumstances. As Holmes (1988) noted, a compliment is a speech act that, explicitly or implicitly, attributes credit to someone other than the speaker, usually the person addressed, for some good (possession, characteristic, skill, etc.), which is positively valued by the speaker and the hearer.

This speech act is composed of two parts: how to make compliments and how to respond to compliments. This paper deals with the former due to the length limitation.

Compliments are considered as expressive speech acts with multiple functions. According to Kerbrat-Orecchioni (2005), compliments are "verbal gifts", aimed at enhancing the face of the recipient. Additionally, compliments could serve as intensifiers of other speech acts or as indirect ways of apologising, thanking, advising, asking for information, etc. Furthermore, compliments may be also used as mitigating devices of face-threatening acts, such as criticism, reprimanding, etc. at the level of discourse organization, whereas some speakers may use compliments as conversation openers (Traverso, 1996). Generally, the speech act of complimenting is perceived as a positive politeness strategy, as it is used to show that the compliment giver notices or attends to the recipient's face desires.

This study chose to examine three situations in which compliments were expressed with regard to: ability and appearance (see Table 6 below). 
Table 6. List of three complimenting situations

\begin{tabular}{ll}
\hline & Situation \\
\hline Complimenting 1 (ability) & Complimenting a classmate on his/her presentation in the English class \\
Complimenting 2 (appearance) & Complimenting a classmate you meet on the street on her new hairstyle \\
Complimenting 3 (appearance) & Complimenting a friend of yours trying on a blouse in a clothing shop \\
\hline
\end{tabular}

The gathered data in these situations were analysed from the aspect of the compliment strategies used and the patterns of compliments.

There are three main compliment strategies: (1) direct compliments; (2) indirect compliments, and (3) compliments with external modifications (Farenkia, 2011).

Direct compliments are realised in an unambiguous manner, by means of occurrences containing devices with positive connotation (e.g. adjectives, adverbs, verbs, verbal constructions, etc.) or performative formulas (e.g. "I congratulate you for the job well done.").

Indirect compliments are expressions of admiration occurring in forms used to realize other speech acts (e.g. advice, wish, promise, request, etc.) and which "need more inferences on the part of the addressee to reconstruct the intended meaning conveyed in the message by the speaker" (e.g. "Please give me the recipe!") (Yu, 2005).

External modification refers to the different kinds of additional speech acts or supportive moves that appear either before or after the direct compliments (single or multiple head acts) and which serve various politeness or relational functions such as mitigating or intensifying the head acts (e.g. "Hi, I am Peter and I really loved your presentation.").

Regarding the patterns of compliments, i.e. the sentence structure, in Coulmas 1981, Wolfson and Manes established the following nine patterns in $97 \%$ of the interactions:

1. NP \{is, looks\} (really) ADJ PP: "Your raincoat is really nice."

2. I (really) \{like, love\} NP: "I really like your hair."

3. PRO is (really) (a) (ADJ) NP: "That's a neat jacket."

4. You V (a) (really) ADJ NP: "You did a (really) good job."

5. You V (NP) (really) ADV PP: "You really handled that situation well."

6. You have (a) (really) ADJ NP: "You have such beautiful hair!"

7. What (a) (ADJ) NP!: "What a lovely baby you have!"

8. ADJ (NP)!: "Nice game!”

9. Isn't NP ADJ!: "Isn't your ring beautiful!'

whereby

$\mathrm{NP}=$ noun phrase

$\mathrm{ADJ}=$ adjective

$\mathrm{PRO}=$ pronoun

$\mathrm{V}=$ verb

$\mathrm{ADV}=$ adverb

In the first situation of complimenting, students were required to compliment a classmate on his/her presentation in the English class. Table 7 below shows the findings of the study related to this situation. 
Table 7. Compliment 1 - Complimenting a classmate on his/her presentation in the English class

\begin{tabular}{|c|c|c|c|c|c|c|c|c|c|c|c|}
\hline \multirow[t]{2}{*}{ ID } & \multirow{2}{*}{$\begin{array}{l}\text { Compliment strategies and } \\
\text { patterns }\end{array}$} & \multicolumn{5}{|c|}{ Frequency of use (numbers) } & \multicolumn{5}{|c|}{ Frequency of use (percentage) } \\
\hline & & $\mathbf{I}$ & II & III & IV & Total & $\mathbf{I}$ & II & III & IV & Total \\
\hline \multirow[t]{9}{*}{ a. } & Compliment $\quad$ with external & 9 & 0 & 5 & 9 & 23 & 15 & 0 & 8.33 & 15 & 9.58 \\
\hline & modification on action & & & & & & & & & & \\
\hline & Pattern: & & & & & & & & & & \\
\hline & You V (NP) (really) ADV PP & & & & & & & & & & \\
\hline & Disarmer: Excuse me for bothering & & & & & & & & & & \\
\hline & you, ... & & & & & & & & & & \\
\hline & $\begin{array}{l}\text { Opener: ... but I would like to tell } \\
\text { you that ... }\end{array}$ & & & & & & & & & & \\
\hline & $\begin{array}{l}\text { Head act: ... you were perfect } \\
\text { during your presentation. }\end{array}$ & & & & & & & & & & \\
\hline & $\begin{array}{l}\text { Desire to emulate: I look forward } \\
\text { to your next presentation! }\end{array}$ & & & & & & & & & & \\
\hline \multirow[t]{7}{*}{ b. } & Direct compliment on the action + & 30 & 32 & 28 & 36 & 126 & 50 & 53.33 & 46.67 & 60 & 52.5 \\
\hline & Pattern: NP \{is, looks $\}$ (really) & & & & & & & & & & \\
\hline & $\begin{array}{l}\text { ADJ } \\
\text { Expression of Praise: Well done! }\end{array}$ & & & & & & & & & & \\
\hline & Head act: Your presentation was & & & & & & & & & & \\
\hline & $\begin{array}{l}\text { Head act: Your presentation was } \\
\text { excellent. }\end{array}$ & & & & & & & & & & \\
\hline & Extension of the compliment: $I$ & & & & & & & & & & \\
\hline & found it really interesting. & & & & & & & & & & \\
\hline \multirow[t]{8}{*}{ c. } & Direct compliment on the action + & 21 & 28 & 27 & 15 & 91 & 35 & 46.67 & 45 & 25 & 37.92 \\
\hline & $\overline{\text { Pattern: I (really) }\{\text { like, love }\} \text { NP }}$ & & & & & & & & & & \\
\hline & Expression of Praise: Bravo! & & & & & & & & & & \\
\hline & Specific address form: $M y$ & & & & & & & & & & \\
\hline & friend, ... & & & & & & & & & & \\
\hline & Expression of admiration: ...you & & & & & & & & & & \\
\hline & rock. & & & & & & & & & & \\
\hline & Head act: I loved it! & & & & & & & & & & \\
\hline
\end{tabular}

As shown above, more than half of the students (52.5\%) opted for the second offered response that was a direct compliment on the action and consisted of the following compliment pattern: NP \{is, looks\} (really) ADJ. This compliment was also supplemented by an expression of praise and an extension. Then, almost $38 \%$ of them indicated the third offered response, i.e. a direct compliment on the action composed of the following compliment pattern: I (really) \{like, love\} NP. This compliment was also enriched by an expression of praise and a specific address form. Only about $10 \%$ of the students chose the first response that, unlike the other two responses, was a compliment with external modification on the action and it had the following pattern: You V (NP) (really) ADV PP. An external modification device (a disarmer) and an internal modification device (an opener) supplemented the compliment. It was also enhanced by an expression of a desire to emulate.

In the second situation, students were supposed to pay a compliment on the hairstyle of the classmate who they met on the street. The frequency of use of the offered responses by the students is shown in Table 8 below.

Table 8. Compliment 2 - Complimenting a classmate you meet on the street on her new hairstyle

\begin{tabular}{|c|c|c|c|c|c|c|c|c|c|c|c|}
\hline \multirow[t]{2}{*}{ ID } & \multirow{2}{*}{$\begin{array}{l}\text { Compliment strategies and } \\
\text { patterns }\end{array}$} & \multicolumn{5}{|c|}{ Frequency of use (numbers) } & \multicolumn{5}{|c|}{ Frequency of use (percentage) } \\
\hline & & $\mathbf{I}$ & II & III & IV & Total & $\mathbf{I}$ & II & III & IV & Total \\
\hline a. & $\begin{array}{l}\text { Direct compliment on both the } \\
\text { object and the person } \\
\text { patterns: What (a) (ADJ) NP! + } \\
\text { You V (NP) (really) ADV PP } \\
\text { Head act: How pretty your hair is! } \\
\text { Head act: You look great,... } \\
\text { Expression of surprise: ... what a } \\
\text { change! }\end{array}$ & 13 & 17 & 19 & 20 & 69 & 21.67 & 28.33 & 31.67 & 33.33 & 28.75 \\
\hline b. & $\begin{array}{l}\text { Direct compliment on both the } \\
\text { object and person } \\
\text { 2 patterns: ADJ (NP)! + You V (a) } \\
\text { (really) ADJ NP } \\
\text { Head act: Cool haircut! } \\
\text { Head act: You're such a cutie! }\end{array}$ & 37 & 34 & 36 & 31 & 138 & 61.67 & 56.67 & 60 & 51.67 & 57.5 \\
\hline
\end{tabular}




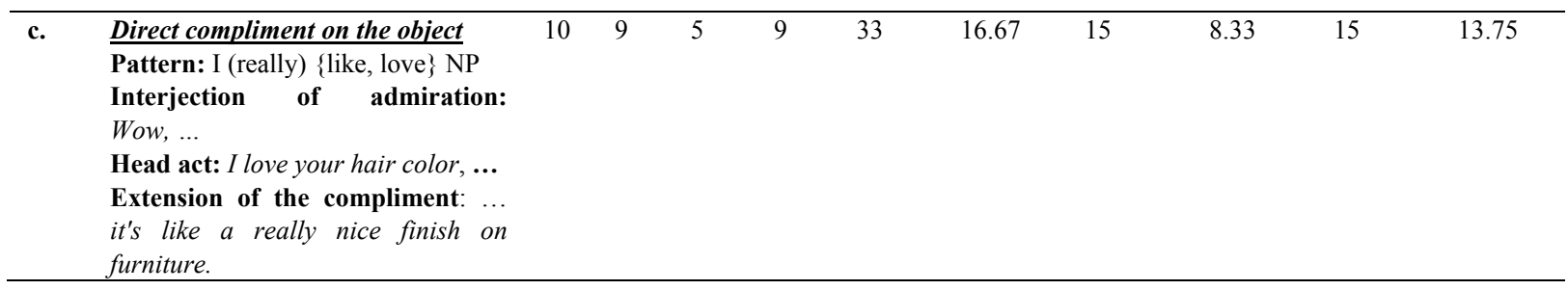

As it can be seen above, all three responses represent direct compliments. About $58 \%$ of the students indicated the second offered response that was a direct compliment on both the object and the person. This compliment was a complex/compound one as it had two head acts with the following patterns: ADJ (NP)! and You V (a) (really) ADJ NP. Around $30 \%$ of the students opted for the first response, which was also a direct compliment on both the object and the person. This compliment was a complex/compound one as well, as it had two head acts with the following patterns: What (a) (ADJ) NP! and You V (NP) (really) ADV PP. This compliment was also enriched by an expression of surprise. The third response, which was a direct compliment on the object, was indicated by almost $14 \%$ of the students. It had the following pattern: I (really) \{like, love\} NP and it was supplemented by an interjection of admiration and additionally extended.

Finally, the third situation was about complimenting a friend that was trying on a blouse in a clothing shop. The results of this situation are presented in Table 9 below.

Table 9. Compliment 3 - Complimenting a friend of yours trying on a blouse in a clothing shop

\begin{tabular}{|c|c|c|c|c|c|c|c|c|c|c|c|}
\hline \multirow[t]{2}{*}{ ID } & \multirow{2}{*}{$\begin{array}{l}\text { Compliment strategies and } \\
\text { patterns }\end{array}$} & \multicolumn{5}{|c|}{ Frequency of use (numbers) } & \multicolumn{5}{|c|}{ Frequency of use (percentage) } \\
\hline & & I & II & III & IV & Total & I & II & III & IV & Total \\
\hline a. & $\begin{array}{l}\text { Direct compliment on the object } \\
\text { an explicit performative verb of } \\
\text { complimenting } \\
\text { Head act: I compliment you on your } \\
\text { new blouse! } \\
\text { Extension of the compliment: It } \\
\text { makes your eyes turn the most } \\
\text { gorgeous shade of blue! }\end{array}$ & 11 & 6 & 5 & 9 & 31 & 18.33 & 10 & 8.33 & 15 & 12.92 \\
\hline b. & $\begin{array}{l}\text { Direct compliment on the object } \\
\text { Pattern: What (a) (ADJ) NP! } \\
\text { What a nice blouse! } \\
\text { Extension of the compliment: It fits } \\
\text { you well! }\end{array}$ & 30 & 36 & 22 & 28 & 116 & 50 & 60 & 36.67 & 46.67 & 48.33 \\
\hline c. & $\begin{array}{l}\text { Direct compliment on the person } \\
\text { Pattern: PRO is (really) (a) (ADJ) } \\
\text { NP } \\
\text { Specific address form: Damn giiirl! } \\
\text { Head act: That blouse looks good on } \\
\text { you! } \\
\text { Expression of contentment: } \\
\text { Mmmm! }\end{array}$ & 19 & 18 & 33 & 23 & 93 & 31.67 & 30 & 55 & 38.33 & 38.75 \\
\hline
\end{tabular}

All compliments in this situation are direct compliments as well. More than $48 \%$ of the students indicated the second response as a direct compliment on the object composed of the following pattern: What (a) (ADJ) NP! . This compliment was additionally extended. Then, almost $39 \%$ of them opted for the third response, a direct compliment on the person with the following pattern: PRO is (really) (a) (ADJ) NP, which was enriched by a specific address form and an expression of contentment. Finally, almost $13 \%$ of the students chose the first response, which was also a direct compliment on the object. What is interesting and specific about this compliment is that it is an explicit performative verb of complimenting, which is rarely used in practice; hence, smaller percentage of the students chose it. This compliment was extended, as well. 
Table 10. Compliment patterns

\begin{tabular}{lll}
\hline Pattern & Number & Frequency \\
\hline You V (NP) (really) ADV PP & 2 & $20 \%$ \\
NP \{is, looks\} (really) ADJ & 1 & $10 \%$ \\
I (really) \{like, love\} NP & 2 & $20 \%$ \\
What (a) (ADJ) NP! & 2 & $20 \%$ \\
ADJ (NP)! & 1 & $10 \%$ \\
You V (a) (really) ADJ NP & 1 & $10 \%$ \\
PRO is (really) (a) (ADJ) NP & 1 & $10 \%$ \\
TOTAL & 10 & \\
\hline
\end{tabular}

As Table 10 shows, the three most frequently used patterns in the present study were the following ones:

You V (NP) (really) ADV PP

I (really) \{like, love $\}$ NP

What (a) (ADJ) NP!

\section{Discussion}

This chapter describes the data analysis by way of triangulation to enhance the accuracy of the study through corroborating evidence from different data sources. The three research questions proposed by this study are addressed in relation to Macedonian high school students' views on and perceptions of pragmatics, their levels of pragmatic competence and their perceptions and practice of language learning strategies employed in the process of learning English and pragmatics.

RQ1: What are the Macedonian high school English language students' views on and perceptions of pragmatics in their English learning process?

The answer to this question is discussed through the results received in the following subpart:

\subsection{Students' Views on and Perceptions of English Language Learning}

English is taught as the first foreign language in Macedonia and it is a compulsory course in primary and high school. As shown in Table 3, almost $75 \%$ of the participants have studied English for more than six years, whereby only $12 \%$ of them had language learning experience in an English-speaking country. It could be concluded that the Macedonian high school English language students are advanced language learners as they have learned English in the Macedonian context for a long period of time and have therefore developed a high level of English language competency.

As noted in Table 3, nearly $90 \%$ of the participants indicated that the main reason they needed to learn English was not to pass the exam. The reason behind this might be the requirement of the Macedonian society for students not only to have relevant English certificates but to obtain practical abilities in order to effectively communicate in English as well. Motivation plays an important role in helping L2 learners to achieve L2 competency (Yuan \& Schen, 2009). Driven by different motivation factors, the majority of the students in the study indicated that they focused more attention on their development of pragmatic knowledge in the English language learning process. This can be seen in the responses presented in Table 2 in the questionnaire, where nearly $81 \%$ of the students agreed that the knowledge of how to use the language is as important as the linguistic knowledge.

Regarding the type of English students wanted to learn, nearly the same percentage of students opted for British English (nearly 50\%) and American English (47\%) (see Figure 2). Whether it was British English or American English, the majority of the students (almost 60\%) wished to speak like native English speakers and they were keen on imitating native speakers' pronunciation and intonation.

These findings practically indicate that students wanted to learn English they could use in everyday settings and learning 'native-like' English was preferred over more traditional language learning. On the other hand, excessive imitation of native speakers, to a great extent, limits non-native speakers' development of pragmatic competence.

RQ2: To what extent do high school English language students in Macedonia focus on their pragmatic knowledge in their English language learning? What are their levels of pragmatic competence?

The answers to this are given in the following two subparts: 


\subsection{Students' Focus on Pragmatic Knowledge in English Language Learning}

The syllabi for English as the first foreign language in secondary education in the Republic of Macedonia, as a compulsory course, are developed based on the Common European Framework of Reference for Languages and the students' achievements in the nine-year elementary education. Moreover, they are informed by relevant research, theories and best classroom practices for language teaching and development of the students' communicative competence. They focus on the lexicology and grammar of the language, development of communicative skills, cultural aspects of the English-speaking countries, etc. Based on this, developing students' pragmatic competence in communication has become a major task in the current high school English learning and teaching process in Macedonia.

High school English language students indicated that pragmatic knowledge is as important as linguistic knowledge. As indicated by Figure 2, they preferred to acquire cultural knowledge, linguistic knowledge, but they did not neglect the need of acquiring communicative skills and knowledge of how to use English as well.

\subsubsection{High School English Language Students' Levels of Pragmatic Competence}

Knowing students' levels of pragmatic competence can provide convincing evidence for language education experts to prepare adequate and effective curriculum and teaching materials. Additionally, language teachers would be more informed of students' needs in the process of learning the target language so that they can better design the classroom teaching and learning to facilitate students to achieve optimal learning outcomes.

Analysing the use of language in communicative situations is regarded as the core business in pragmatics (Haugh, 2009). This study employed DCTs to examine Macedonian high school English language students' levels of pragmatic competence. Three situations related to the speech act of complimenting were used to investigate high school English students' pragmatic competence. The discussion based on the analysis of the findings is presented below.

\subsubsection{Discourse Completion Tasks Data}

Pragmatic competence is the ability to use language forms in a wide range of environments and affects the relationship between the language users and the social and cultural context of the situation (Gass \& Selinker, 2001; Lightbown \& Spada, 1999).

Language users employ a variety of speech acts to achieve their communication aims. As mentioned above, the speech act of complimenting was applied in the DCTs to explore high school English language students' levels of pragmatic competence and the practice of language learning strategies in EFL learning. Students' responses were evaluated from the aspect of the compliment strategies used and the patterns of compliments. The findings of the analysis are presented in details in Chapter 3 - Research Data Report.

\section{Compliments}

Compliments are very often heard in people's daily interactions as expressions of positive evaluation commonly used by interlocutors of equal or higher status.

The research has shown that compliments can be used in a variety of social situations. One of the most important functions of compliments is to reinforce the bond of solidarity between the speaker and the hearer.

Consequently, the data indicated that most of the students used the adequate compliment strategies, as they were probably aware of the relationship between the interlocutors in each situation. They tried to be direct in their expression, although it has to be stressed here that all the responses offered, except for one, employed direct strategies. However, they opted for the most adequate and shortest one, which is sufficiently polite at the same time.

As for the patterns indicated, the three most frequently used patterns in the present study were the following ones:

You V (NP) (really) ADV PP

I (really) \{like, love $\}$ NP

What (a) (ADJ) NP!

RQ3: How do high school English language students apply their language learning strategies in the pragmatics and English learning process?

Language learning strategies are crucial for language learners to develop their communicative ability in the target language (O’Malley \& Chamot, 1990) as they facilitate language learners in obtaining, storing, retrieving 
and using information (Wenden \& Rubin, 1987). The third research question focuses on students' perceptions of language learning strategies in high school English language learning, especially in learning pragmatics. The discussion on the findings is presented in the following sections.

\subsection{Students' Perceptions of Language Learning Strategies}

As defined previously, language learning strategies are among the main factors that help determine how and how well students learn a foreign language. When the language learner consciously chooses strategies that fit their learning style and the L2 task at hand, these strategies become a useful toolkit for active, conscious, and purposeful self-regulation of the learning process. Language learning strategies can be categorized into six groups: cognitive, metacognitive, memory-related, compensatory, affective, and social (Oxford, 1990).

As noted in Figure 4, almost $60 \%$ of the students indicated the method of having conversations and discussions in English in the classroom, which is a social strategy, as the most effective way of learning English. Students also indicated the self-studying and self-evaluation method (nearly $20 \%$ ), as both a cognitive and metacognitive strategy.

Taking into account the student-oriented education nowadays, and the results shown in Figure 5, it can be noted that students do not totally rely on teachers' language knowledge and personal viewpoints to learn the English language. Moreover, as shown in Figure 5, almost 53\% of the students indicated listening to radio programs/dialogues and watching TV programs/videos as their preferred way of getting information about the use of English. $22.5 \%$ of them stated that they would like to get English-related information based on their teachers' explanation.

Furthermore, as indicated in Table 3, most of the students or more precisely, more than $63 \%$ of the participants in this study were females. It is generally accepted that female students are better language learners and language practitioners than male students, so it is reasonably expected for males to have more difficulties in recognising and employing the most suitable language learning strategies for them in order to acquire language knowledge (Larsen-Freeman \& Long 1991; Dionne et al. 2003).

However, $47.5 \%$ of the students indicated that they usually use cognitive strategies to resolve difficulties in English language learning by looking up words in a dictionary or trying to find answers on the Internet, as shown in Figure 6. This strategy was logically followed by the method of trying to solve the problem by themselves, which practically only supplements the first mentioned strategy. Asking the English teacher or another native speaker and discussing and working with their classmates were less preferred strategies for solving problems related to their English learning process by the students - participants in this study.

Another fact that confirms students' lack of knowledge of the possible language learning strategies is the data noted in Figure 4, where less than 10\% of the students indicates doing sentence drills and translation exercises as their least preferred way of learning English or, in other words, they indicated having conversations and discussions in English in the classroom as the most effective way of learning English. This percentage is contradictory to the results displayed in table 6 where nearly $57 \%$ of the students stated that they like grammar and vocabulary explanations and sentence drills in their English class. It is worth noting in this context that the translation method is very often practiced by English teachers in the classroom as it is considered that this kind of practice can indeed improve students' English level since they are able to successfully make the translation between their mother tongue and the target language only when students are fully aware of the target culture and are able to appropriately apply their linguistic knowledge of the target language.

\section{Conclusion}

The findings of this study indicated that current high school English language learning and teaching in Macedonia still concentrated on the development of language learners' linguistic competence although the current curricula for English as the first foreign language clearly proposes a requirement for achieving communicative competence in intercultural communication. High school English language students are unable to obtain adequate pragmatic knowledge used in communication as neither the classroom teaching nor the materials used provide sufficient pragmatic knowledge for them.

As the English teaching process offers only a limited range of opportunities for practising English in authentic ways, high school English language students are not becoming skillful language practitioners. Although they have recognised the importance of acquiring pragmatic knowledge, they are still left to their own ways and devices in the process of acquiring pragmatic knowledge. Due to this, students practically return to older paradigms where the focus is mainly on passing examinations. This, however, limits the possibility for students to develop pragmatic competence. 
Concerning the high school English teaching and learning processes in Macedonia, this study found that both teachers and students focused on the language itself rather than on its pragmatics. Greater attention is paid to language structure and vocabulary instruction rather than to the pragmatics of the language. The cultural aspect of the education is limited to "broad culture", such as festivals and holidays, instead of putting focus on the relationship between language and culture.

Foreign language learning and teaching has a long history in Macedonia, which focused on the language grammar and vocabulary for a long time. They were learned and taught through various strategies, such as translation. This strategy has been widely used in foreign language learning and teaching and criticised due to its lack of focus on development of learners' communicative skills. The improvement of the foreign language curricula in Macedonia by putting focus on the communicative competence and the cultural aspect of the language learning and teaching processes has practically provided directions for reshaping the classroom learning and teaching processes. Thus, the focus in the classroom has been shifted from the traditional teacher-centered language teaching and learning model to the student-centered model.

However, the study found that high school English teaching and learning still focused on the development of students' linguistic competence, such as grammar and vocabulary, even though the improved curricula recommend developing learners' communicative competence and independent language learning abilities.

The findings of the study indicated that most tasks carried out in the English classroom were pragmatic tasks such as pair-work and group discussion, whereas role-play and debate were less often used. Moreover, although half of the students indicated that the textbooks provided pragmatic tasks aimed at developing students' pragmatic competence, a large number of them was neutral, which leads to the conclusion that either students are not sufficiently and effectively engaged in the language learning process or their individual differences and requirements in learning English are often neglected.

The results also show that students' mindset should be changed as well, because the majority of them believed that the English learning process should be focused on learning grammar, vocabulary, and pronunciation. That is to say, they believed that pragmatic competence is as important as linguistic competence. As a result of this, students' preferences and understanding of the importance of the pragmatic competence might become obstacles in developing their pragmatic knowledge. Hence, the present high school English teaching and learning processes provide limited opportunities for students to practise communication in the classroom, much less practice of spontaneous communication in real contexts outside the classroom. Since these high school students are not able to obtain adequate pragmatic materials and practice opportunities, it is understandable that their level of pragmatic competence is not as high as it should be.

\section{References}

Austin, J. L. (1962). How to do things with words. New York: Oxford University Press.

Bamgbose, A. (2001). World Englishes and globalization. World Englishes, 20(3), 357-363. https://doi.org/10.1111/1467-971X.t01-1-00220

Bardovi-Harlig, K., \& Dörnyei, Z. (1998). Do language learners recognize pragmatic violations? Pragmatic versus grammatical awareness in instructed L2 learning. TESOL Quarterly, 32(2), 233-262. https://doi.org/10.2307/3587583

Barron, A. (2003). Acquisition in interlanguage pragmatics: Learning how to do things with words in a study abroad context. Amsterdam: John Benjamins Publishing Company. Retrieved from https://books.google.mk/books?id=rWhHhRJqS5oC\&printsec=frontcover\&source=gbs_ge_summary_r\&ca $\mathrm{d}=0 \# \mathrm{v}=$ onepage \& $\mathrm{q} \& \mathrm{f}=$ false

Blum-Kulka, S. (1982). Learning how to say what you mean in a second language: A Study of the Speech Act Performance of Learners of Hebrew as a Second Language. Applied Linguistics, 3, 29-59. https://doi.org/10.1093/applin/III.1.29

Cohen, A. D. (1996). Speech Acts. In S. L. Mckay \& N. H. Homberg (Eds.), Sociolinguistics and Language Teaching (pp. 383-420). Cambridge: Cambridge University Press.

Coulmas, F. (1981). 'Poison to your soul': Thanks and apologies contrastively viewed. In F. Coulmas (Ed.), Conversational routine (pp. 69-91). The Hague: Mouton.

Denscombe, M. (2007). The good research guide: for small-scale social research projects. Maidenhead: Open University Press.

Dionne, G., Dale, P. S., Boivin, M., \& Plomin, R. (2003). Genetic evidence for bidirectional effects of early 
lexical and grammatical development. Child Development 74(2), 394-412. https://doi.org/10.1111/1467-8624.7402005

Farenkia, B. M. (2011). Speech acts and regional variations in French: the case of compliments on skills in Cameroon and Canadian French. Speech and Context, 2(III). Retrieved from http:/oaji.net/articles/2014/941-1404304236.pdf

Gass, S., \& Selinker, L. (2001). Second language acquisition: An introductory course. Mahwah, NJ: Lawrence Erlbaum Associates, Inc. Retrieved from https://blogs.umass.edu/moiry/files/2015/08/Gass.Second-Language-Acquisition.pdf

Grassel, E., \& Schirmer, B. (2006). The use of volunteers to support family careers of dementia patients: results of a prospective longitudinal study investigating expectations towards and experience with training and professional support. Zeitschrift Fur Gerontologie Und Geriatrie, 39(3), 217-226. In Z. Zainal (2007). Case study as a research method. Jurnal Kemmanusiaan bil.9. Universiti Teknologi Malaysia. Retrieved from https://jurnalkemanusiaan.utm.my/index.php/kemanusiaan/article/view/165/158

Gülseçen, S., \& Kubat, A. (2006). Teaching ICT to teacher candidates using PBL: A qualitative and quantitative evaluation. Educational Technology \& Society, 9(2), 96-106. Retrieved from https://pdfs.semanticscholar.org/1d7c/befa358c7582261ada7c66c47b7ee8d52738.pdf

Haugh, M. (2009). Intention(ality) and the conceptualization of communication in pragmatics. Australian Journal of Linguistics, 29(1), 91-113. https://doi.org/10.1080/07268600802516301

Holmes, J. (1988). Paying compliments: A sex-preferential politeness strategy. Journal of Pragmatics, 12. In Y. Duan (2011). A pragmatic research report on compliment speech act. Theory and Practice in Language Studies, 1(4), 356-360. Finland: ACADEMY PUBLISHER. Retrieved from http://www.academypublication.com/issues/past/tpls/vol01/04/06.pdf

Hymes, D. H. (1972). On communicative competence. In J. B. Pride \& J. Holmes (Eds.), Sociolinguistics. Selected Readings (pp. 282-293). Harmondsworth: Penguin. Retrieved from http://wwwhomes.uni-bielefeld.de/sgramley/Hymes-2.pdf

Ji, P. (2008). Pragmatics and pedagogy in College English teaching. Shanghai: Shanghai Foreign Language Education Press. In Y. Yuan. (2012). Pragmatics, Perceptions and Strategies in Chinese College English Learning. Ph.D. Thesis, Queensland University of Technology. Retrieved from http://eprints.qut.edu.au/52860/1/Yifeng_Yuan_Thesis.pdf

Johnson, M. P. (2006). Decision models for the location of community corrections centers. Environment and Planning B-Planning \& Design, 33(3), 393-412. In Z. Zainal. (2007). Case study as a research method. Jurnal Kemmanusiaan bil, 9, 1-6. Universiti Teknologi Malaysia. Retrieved from http://psyking.net/htmlobj-3837/case_study_as_a_research_method.pdf

Kaplan, R. B. (2002). The Oxford handbook of applied linguistics. New York: Oxford University Press.

Kasper, G. (1996). Introduction: interlanguage pragmatics in SLA. Studies of Second Language Acquisition, 18, 145-148. In L. Cai \& Y. Wang. (2013). Interlanguage Pragmatics in SLA. Theory and Practice in Language Studies, 3(1), 142-147. Finland: ACADEMY PUBLISHER. Retrieved from https://pdfs.semanticscholar.org/6f88/2b5812d9aa48a283a11f6ee2b0410120a573.pdf

Kerbrat-Orecchioni, C. (2005). Les actes de langage dans le discours. Paris: Armand Colin. In B. M. Farenkia. (2011). Speech acts and regional variations in French: the case of compliments on skills in Cameroon and Canadian French. Speech and Context, 2(III), 1-19. Retrieved from http:/oaji.net/articles/2014/941-1404304236.pdf

Larsen-Freeman, D., \& Long, M. H. (1991). An Introduction to Second Language Acquisition Research. New York, NY: Longman.

Levinson, S. C. (1983). Pragmatics. Cambridge: Cambridge University Press.

Lightbown, P. M., \& Spada, N. (1999). How languages are learned. Oxford: Oxford University Press.

Ministry of Education and Science, Bureau for Development of the Education. (September, 2015). Syllabus for the First Foreign Language - English (for the $2^{\text {nd }}$ year of the regular secondary education). Skopje.

Mott, B. L. (2003). Introductory semantics and pragmatics for Spanish leaners of English. Barcelona: Edicions Universitat Barcelona. Retrieved from http://www.publicacions.ub.edu/refs/indices/07088.pdf 
Oxford, R. L. (1990). Language learning strategies: What every teacher should know. New York: Newbury House.

Pütz, M., \& Neff-van Aertselaer, J. (2008). Introduction: Developing contrastive pragmatics. In M. Pütz \& J. Neff-Aertselaer (Eds.), Developing Contrastive Pragmatics: Interlanguage and Cross-Cultural Perspectives (pp. 9-18). Berlin and New York: Mouton de Gruyter. Retrieved from https://www.scribd.com/document/364980296/Developing-Contrastive-Analysis

Searle, J. R. (1969). Speech Acts. Cambridge: Cambridge University Press. https://doi.org/10.1017/CBO9781139173438

Searle, J. R. (1971). What is a speech act? In J. R. Searle (Ed.), The Philosophy of Language (pp. 39-53). London: Oxford University Press.

Searle, J. R. (1975). Indirect speech acts. In P. Cole \& J. L. Morgan (Eds.), Syntax and semantics, Vol. 3. Speech Acts (pp. 59-82). New York, NY: Academic Press.

Searle, J. R. (1976). The classification of illocutionary acts. Language in Society, 5(1), 1-23. Retrieved from https://www.scribd.com/document/294761190/A-Classification-of-Illocutionary-Acts-searle-an

Searle, J. R. (1979). A taxonomy of illocutionary acts. In J. R. Searle (Ed.), Expression and Meaning (pp. 1-29). Cambridge: Cambridge University Press.

Takkaç T., A. (2016). The role of pragmatic competence in foreign language education. Turkish Online Journal of English Language Teaching (TOJELT), 1(1). 10-19. Retrieved from http://dergipark.ulakbim.gov.tr/tojelt/article/view/5000154848/5000151472

Traverso, V. (1996). La conversation familière. Analyse pragmatique des interactions. Lyon: Presses Universitaires de Lyon.

Wenden, A., \& Rubin, J. (Eds.). (1987). Learner Strategies in Language Learning. Hemel Hempstead: Prentice Hall International.

Widdowson, H. G. (1992). Communication, community, and the problem of appropriate use. A paper presented at the Georgetown University Round Table on Languages and Linguistics. In Y. Yuan. (2012). Pragmatics, Perceptions and Strategies in Chinese College English Learning. Ph.D. Thesis, Queensland University of Technology. Retrieved from http://eprints.qut.edu.au/52860/1/Yifeng_Yuan_Thesis.pdf

Wittgenstein, L. (1953). Philosophical investigations. Oxford: Wide, Henning. Retrieved from https://static1.squarespace.com/static/54889e73e4b0a2c1 f9891289/t/564b61a4e4b04eca59c4d232/1447780 772744/Ludwig.Wittgenstein.-.Philosophical.Investigations.pdf

Yin, K. R. (2003). Case study research : design and methods (3rd ed.). London: Sage Publications.

$\mathrm{Yu}, \mathrm{M}$. (2005). Sociolinguistic competence in the complimenting act of native Chinese and American English speakers: a mirror of cultural value. Language and speech, 48(1).

Yuan, Y., \& Shen, H. (2009). Pedagogy, practice and students' motivation: Voices from College English classrooms. In H. Shen (Ed.), Developments and prospects of English Teaching in China (pp. 21-43). Shanghai: Fudan University Press.

Yule, G. (1996). Pragmatics. Oxford: Oxford University Press.

Zhang, D. (2001). The speech act of complaining: a cross-cultural comparative study of Chinese and American English speakers. Retrospective Theses and Dissertations. Paper 16213. Retrieved from https://lib.dr.iastate.edu/cgi/viewcontent.cgi?referer=https://www.google.com/\&httpsredir=1\&article=1721 $2 \&$ context $=$ rtd 


\section{Appendix A}

\section{Questionnaire}

Instructions: As part of the research on 'The Use of English Speech Acts by Macedonian Learners of English' conducted for the purposes of the master thesis titled Reconsidering English Speech Acts and Their Use by Macedonian Learners of English, we would kindly ask you to help us by completing this questionnaire about your pragmatic knowledge and your language learning strategies. This is not a test so you do not need to write your name on it. We are interested in your personal experiences and your views. The information obtained will be kept confidential and used only for the purposes of the academic research. Thank you for your participation and help.

Section I Demographic information

Please choose your answer from the following choices or write it down where required.

1. What is your gender?
A. Male
B. Female

2. What is your age?

3. Which school year are you currently attending?
A. I
B. II
C. III
D. IV

4. What is your major?

5. How many years have you learned English as your second language?

6. Have you ever been to an English-speaking country to study English?
A. Yes
B. No

7. Have you ever been to an English-speaking country for any other purposes (private visit, work, etc.)
A. Yes
B. No

8. Have you ever had or do you now have a native English-speaking teacher?
A. Yes
B. No 
Section II Your views on pragmatics in high school English learning and teaching process.

Part A: Please choose only one answer to each question based on the scale from 1-5 (Note 1).

$1=$ Strongly disagree

$2=$ Disagree

$3=$ Neutral

$4=$ Agree

$5=$ Strongly agree

9. I believe learning English means learning English grammar, $\begin{array}{llllll}1 & 2 & 3 & 4 & 5\end{array}$ vocabulary, and pronunciation.

10. I think that the knowledge of how to use the language is as $\begin{array}{llllll}1 & 2 & 3 & 4 & 5\end{array}$ important as the linguistic knowledge (e.g. vocabulary and grammar)

11. The main reason why I need to learn English is to pass the exam. $\begin{array}{llllll}1 & 2 & 3 & 4 & 5\end{array}$

12. High school English textbooks provide a lot of information on $\begin{array}{lllll}1 & 2 & 3 & 4 & 5\end{array}$ culture, conversation rules, usage, and on how to use English correctly.

13. Communicative activities are a waste of time in the English $1 \begin{array}{lllll}1 & 2 & 3 & 4 & 5\end{array}$ class.

14. I admire the people who can communicate with others in English $\quad 1 \quad \begin{array}{lllll}1 & 2 & 3 & 4 & 5\end{array}$ fluently and accurately.

15. I think teachers should teach us how to communicate with people $\begin{array}{llllll}1 & 2 & 3 & 4 & 5\end{array}$ and how to use English appropriately in the classroom instead of focusing on grammar and vocabulary.

16. The tasks given to us in the English class provide me with $\begin{array}{llllll}1 & 2 & 3 & 4 & 5\end{array}$ knowledge and skills to improve my ability to use English appropriately.

17. I prefer my English class to be focused on communicative $\begin{array}{llllll}1 & 2 & 3 & 4 & 5\end{array}$ language teaching and practice, with grammar explained when necessary.

18. I like grammar and vocabulary explanation, and sentence drills $\begin{array}{llllll}1 & 2 & 3 & 4 & 5\end{array}$ in my English class.

19. I wish to speak like native English speakers and imitate their $\begin{array}{llllll}1 & 2 & 3 & 4 & 5\end{array}$ pronunciation and intonation.

Part B: Please choose only one answer from the following choices to each question (Note 2).

20. Which English would you like to learn to use it most?
A. Macedonian English
B. American English
C. British English

21. What tasks do your teachers most often use in the classroom teaching?
A. Group discussion
B. Pair-work
C. Role-play
D. Debate 
22. How would you like to get information about the use of English?
A. Teacher's explanation
B. Classroom discussion
C. Listening to radio programs/dialogues and watching TV programs/videos
D. Self-study

23. What kind of abilities do you want to develop most in learning English?
A. Ability to communicate with people
B. Ability to do well in English examinations
C. Ability to read materials related to my major
D. Ability to translate

24. What kind of knowledge do you want to acquire most in your English classroom?
A. Linguistic knowledge (e.g. grammar, vocabulary and pronunciation)
B. Cultural knowledge
C. Communicative skills
D. Knowledge of how to use English

25. When you face some difficulties in English learning, what do you usually do first?
A. Ask the English teacher or another native speaker
B. Discuss and work with your classmates
C. Try to solve the problem by yourself
D. Look up a dictionary or try to find the answer on the Internet

26. What is the most effective way of learning English, according to you?
A. Memorising vocabulary and reciting texts
B. Doing sentence drills and translation exercises
C. Having conversations and discussions in English in the classroom
D. Self-studying and self-evaluation

\section{Appendix B}

\section{Discourse Completion Tasks (DCTs)}

Instructions: As part of the research on the use of English speech acts by Macedonian learners of English conducted for the purposes of the master thesis titled "Reconsidering English Speech Acts and Their Use by Macedonian Learners of English", we would kindly ask you to help us by completing these Discourse Completion Tasks and by providing your answer in the following speech situations in English. This is not a test so you do not need to write your name on it. The aim of this DCT is to establish the strategies of expressing certain speech acts that you apply when using the English language as a foreign language. Thus, your answers would help us determine the effect of your source language on your knowledge of the foreign language. Thank you for your participation and help.

Directions: Please read the following speech situations - there are three speech situations for the speech act of complimenting. You are expected to choose the most adequate answer in each speech situation according to you, i.e. the expression you would give naturally when directly answering in English in such a speech situation. You have 30 minutes to finish the following tasks.

\section{Complimenting}

1. One of your classmates has just given a presentation in English class. You really enjoyed the presentation so you approach and compliment him on the great presentation he has just made. You say: (Note 3)

a. Excuse me for bothering you, but I would like to tell you that you were perfect during your presentation. I look forward to your next presentation! 
b. Well done! Your presentation was excellent. I found it really interesting.

c. Bravo! My friend, you rock. I loved it!

2. You meet one of your classmates on the street during the weekend. You notice her new hairstyle. You say: (Note 4)

a. How pretty your hair is! You look great, what a change!

b. Cool haircut! You're such a cutie!

c. Wow, I love your hair color, it's like a really nice finish on furniture.

3. As you are entering a clothing shop, you see your friend trying on a blouse that fits her/him best. He/she decides to buy the blouse. You say:

a. I compliment you on your new blouse! It makes your eyes turn the most gorgeous shade of blue! (Note 5)

b. What a nice blouse! It fits you well!

c. Damn giiirl! That blouse looks good on you! Mmmm! (Note 6)

\section{Notes}

Note 1. Yuan, Y. (March, 2012). Pragmatics, Perceptions and Strategies in Chinese College English Learning, Centre for Learning Innovation, Faculty of Education, Queensland University of Technology.

Note 2. ibid.

Note 3. Farenkia Mulo, B. (2011). Speech Acts and Regional Variations in French: The Case of Compliments on Skills in Cameroon and Canadian French, Speech and Context, 2(III).

Note 4. Peng Xiamei, Z. Y. (2014). Compliment: A Cross-Cultural Study of Speech Act Awareness: A Pilot Project Report. Canadian Social Science, 10(5), 93-98.

Note

http://www.girlsaskguys.com/flirting/q98421-how-to-compliment-girl-on-cute-outfit-without-being-heavy-or-cre $\underline{\text { epy }}$

Note 6. ibid.

\section{Copyrights}

Copyright for this article is retained by the author(s), with first publication rights granted to the journal.

This is an open-access article distributed under the terms and conditions of the Creative Commons Attribution license (http://creativecommons.org/licenses/by/4.0/). 